\title{
The Great Hip Hop Grant Scandal
}

GRAEME WHIMP

Fuarosa and Saralia Tamati, mother and daughter of Samoan origin, were community and youth workers based respectively in Christchurch and Wellington; Saralia was also a hip hop practitioner in the persona of Spexone. In the first half of 2003 , they devised a project in which they would explore the journey of hip hop from New York, through the Pacific Islands, to Aotearoa New Zealand, with a view to applying the insights gained thereby to a variety of community development and Polynesian youth initiatives.' They applied successfully to the Community Employment Group for a social entrepreneur grant, travelled in pursuit of their project between July and September and reported in October 2003. They proceeded to apply their experience to a variety of programmes inside and outside their regular employment. ${ }^{2}$ From March to September 2004, the construction of the Tamati project and grant as a sustainable scandal permitted a continuing political campaign, with accompanying press coverage, that resulted in the closure of the Community Employment Group. The particular circumstances, components and process of that construction provide a sharp and distinctive perspective on the emergence and maintenance of public narratives in Aotearoa New Zealand.

Regular consumers of the news media will recognise the device of constantly repeating a small selection of elements from a more complex story for the purpose of constructing and maintaining a media narrative. Less readily apparent, for obvious reasons, is the corresponding device of suppressing important elements of the story, elements that are often publicly available elsewhere, in order to sustain the viability and force of the chosen elements and, thereby, the narrative. The resulting tabloid plateau of discussion is a fruitful field for the creation of villains and victims, battlers and bludgers. The purpose of this study is to examine one such episode in detail, not so much to reveal why such essentialising occurs as to discover how it unfolds.

To that end I shall draw on theories of moral panics to analyse the construction of the scandal and background that construction by setting out the original objectives of the funding bodies and the results of the audit of the particular grant and the procedures employed in making it. I shall also summarise the information about the grant available at an early stage from 
parliamentary sources. I shall then review the press coverage ${ }^{3}$ to explore the unfolding of the media narrative, a particularly tight and cohesive one, and analyse some of the processes and relationships at work in this narrative.

Making use of a framework derived from Hayden White, I shall identify four elements in the press's creation of the public narrative of the scandal: the imposition of a particular order on events by selection and exclusion in the press coverage; reference to the authority of the hard-working taxpayer; moralising in relation to those other than the hard-working taxpayers, whether idle or sinister; and delivery of the conclusion, the closure, demanded by that moralising. ${ }^{4}$ I shall demonstrate that the principals in the construction of the scandal, Katherine Rich, National party spokeswoman for social welfare at the time, and Anna Claridge, a journalist at the Press in Christchurch, were united in parallel but separate pursuits of closure and that the success of the scandal was a result of the invisibility of Claridge as narrator and the presentation of Rich as commentator rather than protagonist. Finally, I shall consider some aspects of the work performed by the scandal.

The point of this particular investigation is not to find the Tamatis innocent or guilty of the charges that emerged; nor, for that matter, to find the journalists innocent or guilty; it is to determine the way in which the narrative itself appeared and the purposes it served. Readers may be able to form views on those other questions but they are not at issue here. It is appropriate, however, at this point to declare that this paper, too, is constructed and should be read with all the caution and care that involves.

\section{The construction of scandals.}

David L. Altheide observes that control over the process of definition of a situation is a significant act of social power and that the reiteration of associated words and images forms powerful symbolic linkages. ${ }^{5}$ Murray Edelman notes that 'images', in that context, refers not only to 'icons' but also to 'indices', 'terms that lead the mind in a particular direction ... ': the absence of pictorial representation by no means inhibits the formation of mental images. ${ }^{6}$ Stuart Hall and others add that, through their power to define a situation, not just in terms of what happened, but also in terms of how to understand the events, the mass media deliver a primary interpretation into which any opposing interpretations are compelled to insert themselves.?

Another perspective on the role of mass media as agents of moral indignation in defining issues is provided by Stanley Cohen's concept of 'inventories', 'elements of fantasy, selective misperception and the deliberate creation of news ... not reflective stock-taking but manufactured news ${ }^{9}{ }^{8}$ Edelman takes up a similar theme, noting the frequent incidence of resentment based on fantasy and 'energized by the perceived advantages for 
some of creating and disseminating such beliefs, beliefs which are impervious to the existence of clear evidence against them.?

Cohen provides a convincing alternative to more facile conspiracy theories in identifying the primacy and inter-relationship of the institutionalised need to create news and the selective and inferential structure of the news-making process' in constructing deviance inventories. ${ }^{10}$ To these, Hall and others add the importance of the moment of construction and its inherent imperative to ensure comprehensibility to an assumed audience, with an accompanying establishment of identification and contextualisation." Cohen also observes that ambiguity is fertile soil for the generation of scapegoating. ${ }^{12}$

Cohen's inventory concept is an element in his development of a theory of 'folk devils and moral panics'. He commences his analysis of the 'mods and rockers' phenomenon in 1960s Britain with this description of moral panics:

A condition, episode, person or group of persons emerges to become defined as a threat to societal values and interests; its nature is presented in a stylized and stereotypical fashion by the mass media; the moral barricades are manned by editors, bishops, politicians and other rightthinking people ... ${ }^{13}$

Later he concludes that

. . . a theory of moral panics, moral enterprise, moral crusades or moral indignation needs to relate such reactions to conflicts of interests - at community and societal levels - and the presence of power differentials which leave some groups vulnerable to such attacks. The manipulation of appropriate symbols - the process which sustains moral campaigns, panics and crusades - is made much easier when the object of attack is both highly visible and structurally weak. ${ }^{14}$

In drawing on this range of perspectives on the construction of moral panics, 1 shall argue that the great hip hop grant scandal was, in essence, a variety of moral panic promoted by the articulation of resentment at the idea of the waste of taxpayers' money, envy of the luxurious connotations of international travel and fear of the transgressive associations of hip hop.

\section{The funding bodies}

The Community Employment Group (CEG) was established by the Labour government to promote '[s]uccessful local community enterprise and employment development for communities disadvantaged in the labour market'. Its brief was to work 'with communities that face a range of disadvantage in the labour market: in particular Maori, Pacific peoples, women, and those living in disadvantaged urban and rural areas'. ${ }^{15}$ In the 2003-2004 year it had a budget of a little over $\$ 23$ million, ${ }^{16}$ and funded 872 
community projects in vulnerable communities, 58 community employment organisations, fourteen social entrepreneur grants, 68 Māori and Pacific women's leadership projects and sixteen projects to create local partnership between Māori groups and other organisations or agencies. ${ }^{17}$

The purpose of the CEG's $\$ 750,000$ Social Entrepreneur Fund (SEF), as recorded in the relevant Cabinet minute, was to 'fund improvements to the ability of community organizations to improve the social and economic well-being of their communities by investing in the capacity of their present leaders and potential leaders'. ${ }^{18}$ The definition of social entrepreneur approved by the minister included taking 'the same approach to risk, opportunity and innovation as a business entrepreneur, but in pursuit of social rather than commercial objectives'. The fund was open to community-sponsored individuals 'showing leadership in the area of community employment development', with specific proposals for discrete projects intended to build capacity. Funding was to be available for 'anything that will assist a social entrepreneur to build their capacity, e.g. child care, travel, course fees, backfilling salary...'. The only exceptions were where other government assistance was available, and where funding was provided for capital expenditure. ${ }^{19}$ In 2002-2003, its last full year, the fund supported 53 projects. ${ }^{20}$ It was frozen in August 2003 and its funding was later taken up by the new Community Initiatives Fund in the Ministry of Social Development. ${ }^{21}$

\section{The audit report}

In March 2004, the acting minister for social development and employment requested a review of a number of CEG-funded grants, including the Tamati grant. The internal audit of that grant was conducted by the Department of Labour chief internal auditor and two internal auditors, with quality assurance provided by Audit NZ. The report was released on 1 September 2004. It is characterised by extremely cautious language and the expectation of a very high standard of documentary evidence. It covers two principal areas: the operations of the CEG itself, including aspects of its relationship with the recipients, and the performance of the recipients.

The report recorded a number of criticisms of the processes used by the CEG but found it 'not unreasonable . . . to conclude that the grant application fitted the funding eligibility criteria' and that there was 'no reason to believe that the conflicts of interest identified were not dealt with appropriately'. ${ }^{22}$ It noted the strong community development, youth work and entrepreneurial aspects of the original application and the suitability of the applicants to carry out that work..$^{23}$ The auditors' overall assessment was that most of the objectives and all the reporting requirements and other terms and 
conditions of funding had been met and that the level of expenditure was appropriate. ${ }^{24}$

A good deal of information about the overseas travel emerged from the audit report. Because of a decision that it would not be worthwhile in terms of the project's objectives to travel to Pago Pago, the duration of the trip was reduced from 73 to 53 days. ${ }^{25}$ The auditors were advised independently by the travel agent that, in order to get the most economical fares for the target destinations, it would be necessary to travel through Europe for a stay of at least 24 hours; the recipients chose Paris for the stopover and stayed there for a total of 27 hours, with 'only essential food and accommodation expenses [being] incurred on that stopover', a total of $\$ 360$. $^{26}$ Similarly, although the airline refused to provide confirmation of the necessary duration for reasons of confidentiality, the recipients were required to have a stopover in Fiji in the absence of a direct flight from Hawai'i to Samoa. ${ }^{27}$ Average expenditure per person per day for accommodation, meals and incidentals was $\$ 100$, and this minimal figure was, apparently, achieved by staying with family or in safe backpackers' hostels. ${ }^{28}$

Most of the facts about the Tamati grant that would eventually appear in the audit report were discoverable in the formative stages of the press coverage of the story, not least through the publication of answers to parliamentary questions. The paucity and selectivity of the facts that did appear in the print media raise serious questions about the formation of the reportage, particularly in view of the claim of Anna Claridge of the Press to have conducted a 'three-week investigation'. ${ }^{29}$ The narrative that emerged in the print media could not have done so if newspaper reports had been based on all the available information. What eventuated was a greater than usual imbalance between coverage of context and events and the construction of the over-arching narrative, a distortion that would continue even after the release of the audit report.

\section{The parliamentary background}

The online file of parliamentary written questions and answers for February 2004 records 109 questions about the Community Employment Group from Katherine Rich, National party spokeswoman for social welfare, to Steve Maharey, Minister for Social Development and Employment. ${ }^{30}$ Of those questions, 90 concerned the outcomes of individual projects receiving CEG grants, 89 of which were in the format of '[w]hich specific objectives were not met by ... and what are the reasons for the objectives of this project not being met?' or '[w]hich specific project objectives were "waived" for ... and what are the reasons for these objectives of this project being waived?' The question about the Tamati grant alone read: 'Can the Minister explain why $\$ 26100$ of taxpayer funds has been used to support a Social 
Entrepreneur project which has a project purpose summarized as "for 2 people to do a whole lot of travelling for hiphop"?' In a foretaste of what would become a central element of the press coverage, it was the only one of all the questions that refers to taxpayer funding. Maharey's 26 February reply outlined the purpose of the SEF and referred to youth programme initiatives resulting from the travel. ${ }^{31}$

The same record for March 2004 contains 111 written questions from Rich and answers from Maharey concerning the CEG. Of those questions, 72 were follow-up questions about separate social entrepreneur grant projects whose final reports had been said to be lacking in detail, 22 sought specific project objectives of other individual projects, and three concerned the performance of an individual employee. The only social entrepreneur grant to have received sustained questioning was the Tamati one, with eleven direct questions about the project itself and a further three about an associated matter. ${ }^{32}$ Those three questions, dated 24 March 2004, asked whether CEG funding had ever 'been used to pay for any form of body tattooing'. On 25 March 2004, a story by Anna Claridge appeared in the Christchurch paper, the Press, attempting to associate Creative New Zealand funding for a 1996 Pacific Underground stage show which included the tattooing of Vic Tamati, Fuarosa Tamati's husband, with the CEG grant. ${ }^{33}$

The eleven questions about the project itself covered its itemised budgeted and actual costs, 'the actual text of any project objectives', the resulting youth programmes, possible Department of Labour or Ministry of Social Development funding to Fuarosa Tamati's employer, funding to a project established as an outcome of the Tamati project, the texts of two supporting references and a stopover in Paris. Three separate questions asked if there had been funding from any of the minister's portfolios respectively to Fuarosa Tamati. ${ }^{34}$ Maharey's replies of 3 and 19 March set out objectives, budget and actual costs, an exhaustive description of the project, the extensive community and youth experience of the grant recipients and a more detailed list of successful outcomes since their return. The replies made clear the project focus on Polynesian entrepreneurship in both youth-development and performing-arts contexts. ${ }^{35}$

Other answers from 22 to 24 March 2004 indicated that there had been no other funding from the minister's portfolios to Fuarosa Tamati, also referred to as Losa and Rose, or to her employer; that the CEG had funded to the extent of $\$ 3971$ two other successful projects mounted by an organisation with which the Tamatis had an association; that the Paris stopover had not been in the original budget; and that no CEG funding had been approved for body tattooing. Maharey also provided the texts of two references supporting the project application and giving further details of the suitability of Fuarosa Tamati to carry out the project. ${ }^{36}$ 


\section{The construction of the Great Hip Hop Grant Scandal}

The major elements of the great hip hop grant scandal were assembled on 17 and 18 March 2004, remained firmly in place until the Community Employment Group was disbanded in late September and the story began to fade, continued to reappear sporadically into December and still emerge in passing reference from time to time. It is not possible to ascertain the exact nature of the interaction between National party welfare spokeswoman Katherine Rich and Christchurch Press journalist Anna Claridge; it may, indeed, have been totally at arm's length, with the journalist deriving her information from the record of written parliamentary questions. While the immediacy of some responses to that information, as in the case of the Vic Tamati tattoo story, makes that seem a little implausible, it is the coincidence of the narrative and political imperatives that is more fundamental, and more interesting, with each demanding its own particular form of closure.

On 17 March 2004, a front-page story by Claridge drew on the parliamentary questions to establish the initial stimuli to the scandal. In this story three discourses predominate: those on taxpayer funds, travel and hip hop. ${ }^{37}$ A second Claridge front-page story on 18 March 2004 maintained those discursive references with further repetitions of taxpayers, travel and hip hop. From what appears to have been an interview with Fuarosa Tamati, she is quoted, in relation to the Fiji stopover, as saying that '[w]e went to Hawaii and Fiji, but that was basically to chill out'. This became the fourth major component of the scandal. That report also established two minor themes that would play throughout the coverage: that Fuarosa Tamati was 'not a hip-hop expert', and that '[n]othing major came from the trip' ${ }^{38}$ It would surely not be excessively partisan to suggest that throwaway comments in the course of an interview exchange were here elevated to the status of fundamental, and only, truth.

The three major discourses were consolidated in an 18 March 2004 National party press release by Rich. In the 261-word release there were five references to taxpayers, nine to travel and chilling out, and eight to hip hop. ${ }^{39}$ As well as containing references to lack of expertise and lack of major outcomes from the trip, this release reinforced the 18 March Press story's introduction of the practice, one that would become virtually universal, of repeating 'hip-hop investigative tour' and 'two people to do a whole lot of travelling for hip-hop'. A further refinement of the travel discourse appeared with the emergence of the 'undisclosed' Paris stopover. ${ }^{40}$ The release of the Department of Labour internal audit on I September 2004 did receive some acknowledgement in the print media. This included Claridge's report that 'the Christchurch mother and daughter escaped criticism', Tara Ross's Sunday Star-Times explanation of the reason for the Paris stopover and Leah 
Haines's outline in the Dominion Post of some of the broader aspects of the Tamati project. ${ }^{41}$ The hip hop/taxpayer/travel/chill out scenario, however, was comprehensively reinstated thereafter.

Between March and December 2004, 106 items referring to the Tamati grant appeared in the surveyed newspapers. Hip hop was a significant element in all of them, to the virtual exclusion of any of the other major elements of the project: references to community development, youth and social work, Polynesians and arts-industry development were almost completely absent or isolated, despite their major roles in the project being clearly available on the public record from March and in the audit report from 1 September. In fact, from July at the latest, and in spite of a brief parallel run by a 'gay and lesbian sports study', the CEG was identified, universally, completely and exclusively as 'the hip hop grant agency' or some close variation.

Opposition politicians, the Prime Minister, editorial writers and journalists themselves characterised the 'hip hop' grant as (in order of appearance): ludicrous, scandalous, political correctness gone mad, nonsensical, hairbrained, bizarre, tainting, questionable, loopy, inappropriate, odd, silly, absurd, controversial (thirteen times, a journalists' favourite), indefensible, insulting, repulsive, wrong, wasteful, embarrassing, a debacle, excessive, infamous, disturbing, madcap, dubious, a rort, a fiasco and touchy-feely PC rubbish. Explanations or arguments in support of these characterisations are absent; it appears that the reference to hip hop is seen as sufficient justification for their application. There are no positive references specific to the grant, except those by Fuarosa Tamati, and only three individuals were quoted briefly in support of her work: Christchurch mayor Garry Moore, University of Canterbury lecturer Vernon Andrews and then-Labour MP Tariana Turia. ${ }^{42}$

The print media suggested a range of activities on which the money would better be spent. These included ear grommets for children, hip replacements for the elderly, tax cuts, a good education for Pacific Island children, healthcare for Pacific Island children, the 6000 children waiting to see a social worker, grants to elderly people to pay power bills, women's refuges, Plunkets and such projects as the Kaikoura Whale Watch tourism venture. Recipients of CEG funding receiving positive coverage included the whalewatch project; ${ }^{43}$ a 'gay, vegetarian, pierced, wheelchair-using' comedian's trips to arts festivals for people with disabilities in England and Australia; ${ }^{44}$ and a Lake Coleridge high-country farmers' outdoor lifestyle tourism group. ${ }^{45}$ Other than the absence of any reference to hip hop, there was no indication of how their nature justified funding support in a way that the Tamati grant did not. Ironically, on the business pages of the Dominion Post during this period, a story celebrating the commercial success of a hip hop magazine business venture alluded to its initial 'community funding'. ${ }^{46}$ 
People with whom the Tamatis were contrasted included, above all, taxpayers, but also middle New Zealanders out there doing hard graft, hardworking taxpayers, most New Zealanders, people of all races who slog their guts out to make ends meet, every cleaner who gets up to work at $4.00 \mathrm{am}$, every nurse who has nearly fallen asleep on his or her feet, every police officer who has feared for his or her life, members of the public and the average New Zealander. There was no explanation of the ways in which the Tamatis differed from them.

From time to time, other CEG grants would emerge as possible alternative scandals but, apparently, none were able to sustain the longevity and intensity of the coverage of the Tamati grant. In order of emergence, the descriptions that appeared were: $\$ 7000$ for two women to travel to the United States to study ways of encouraging more gay and lesbian Māori and Pacific Islanders into sport and cultural activities; $\$ 14,000$ for two women to travel to the netball world champs in Jamaica to lobby for the inclusion of a Māori team in future tournaments; $\$ 15,000$ for a Buddhist group to conduct a feasibility study into meditation and education camps; $\$ 1971$ for twelve people to attend a hip hop summit in Auckland; $\$ 1800$ to develop teamwork in a darts and cultural society; $\$ 20,000$ for a woman to travel to the United States to study environmentally friendly housing; and $\$ 115,000$ to help set up a regional television station in the Far North.

The list continues with $\$ 15,000$ for a former Alliance Wellington Central candidate to study for a graduate diploma in economic development at AUT; $\$ 3700$ for a woman to visit art and craft outlets in Melbourne; $\$ 15,000$ for a woman to attend a macadamia-nut symposium in Australia; $\$ 10,410$ for a man to help Māori work on cruise ships in New Zealand; an unspecified amount allegedly used by the Otautahi Mãori Women's Welfare League to pay for a $\$ 10,000$ strip performance; $\$ 2000$ for a Te Kahui family reunion, including a capacity-building wānanga; $\$ 2000$ for a hip hop hui in Hastings; and $\$ 1970$ for a Porirua mental health provider to visit Auckland to look at taro, hibiscus and citrus cultivation. With the exception of the 'lesbian sports study', which continued to receive occasional mention in association with the Tamati grant, the duration of coverage of these projects was generally one story, with some lasting for up to three.

A series of subsidiary scandals proliferated around the central one. Anna Claridge in the Press concentrated her attention on the Tamati family and, particularly, Fuarosa Tamati. Other 'investigations' and 'revelations' produced by Claridge were: that Vic Tamati, Fuarosa Tamati's husband, was a funding adviser to the Department of Internal Affairs; that her brotherin-law was a field worker/adviser for the CEG; that Vic Tamati's friend and fellow funding adviser was a referee for the Tamati project application; that Fuarosa Tamati had previously travelled to Brazil and Trinidad and Tobago 
for an education workshop, funded by community organisations including Presbyterian Support; that Creative New Zealand gave $\$ 5000$ for Fuarosa Tamati's daughter Karoline's group, Sheelaroc, to travel to Australia to perform at the Adelaide Arts Festival; and that a total of $\$ 44,000$ in grants from various agencies had been given to Fuarosa Tamati and trusts with which she was linked.

Other revelations included that, as referred to above, Creative New Zealand provided $\$ 80,000$ for Auckland and Sydney Pacific Underground stage performances, which included the tattooing of Vic Tamati when he was chair of the group; that the Tamati family and trusts or organisations they were involved with had received at least $\$ 130,000$ in government grants since 1992; that Fuarosa Tamati was receiving a salary funded by a grant from the Department of Internal Affairs to her employer, Te Amorangi Richmond; that the Tamati family and trusts or organisations they were involved with or worked for had received at least $\$ 310,000$ in government grants since 1992; that a project on which Fuarosa Tamati worked had failed in that it was unable to complete one of its six objectives; and that Fuarosa Tamati and the Christchurch Community Outsource Trust were under investigation over allegations of misuse of funds (a story that was repeated nineteen days later, but which seems not to have resurfaced). Without commenting further on their accuracy, relevance or sustainability, I suggest that their effect was to renew the element of newsworthiness that permitted repetition of the principal story, the hip hop grant scandal.

Virtually all of the positive aspects and intended outcomes of the Tamati project, publicly available in Maharey's comprehensive ministerial replies of 3 and 19 March, were notably absent from or erased in the press coverage. These included the recipients' modest level of daily expenditure; the promotion of Pacific/Polynesian youth employment; the focus on community development programmes; promotion of entrepreneurship; increased awareness of global issues; development of activity in the multi-media arena; marketing and promotion of the performing arts; the experience, record and qualifications of the recipients; and the work produced since their return.

In addition, there was the comparative absence of Saralia Tamati, and her hip hop persona, Spexone, from the coverage: while Fuarosa Tamati appeared constantly, Saralia was much less frequently present and then almost always in association with her mother. Only twice, the second occurrence a reference to the first, did Saralia stand alone and only in the first report did she speak directly. ${ }^{47}$ Also absent was any reference to the success, including commercial success, of Aotearoa New Zealand hip hop music and, in particular, the popularity of its Pasifika exponents.

The most spectacular absence of all, however, and one that may be associated with the eclipse of Saralia Tamati and the erasure of Aotearoa 
New Zealand hip hop, was of any discussion whatsoever of hip hop itself, or of what it was that made a 'hip hop grant' ludicrous, scandalous, nonsensical, bizarre or even silly. Within the coverage of the Tamati grant there was no explanation of, or reference to, what it was that caused a letter writer to refer to 'the nonsensical American phenomenon of hip-hop garbage', or the editorialist of the Press to assert that 'most members of the public . . . find it extraordinary that this mother and daughter could ever imagine that accepting $\$ 26,000$ for a global hip-hop tour could ever represent a sound use of public money' ${ }^{48}$ Or the leader writer of the New Zealand Herald to suppose that 'surely a grant of $\$ 26,000$ linked to the phrase "hip hop" would have set off alarm bells', and to warn that '[w]oe betide the ministry if the words "hip hop" appear on its files in any context other than the gait of arthritic rabbits'. ${ }^{49}$ Or what it was about a $\$ 26,100$ grant that sustained a six-month political and media campaign resulting in the closure of a $\$ 23$ million government employment programme.

\section{Analysis}

Katherine Rich was clearly the progenitor of the Tamati story and a continuing resource throughout its career. In the press coverage, however, she did not appear as the instigator, as she did in the parliamentary record, but as a commentator on the events as they were narrated. Anna Claridge became the objective narrator, absent from the story in spite of the presence of her by-lines, with other journalists acting as subordinate purveyors of the narrative. Claridge produced 22, over 20 percent, of the 106 items of all kinds and fifteen, over 40 percent, of the 36 substantial stories, breaking every major development except the content of the audit report, and reiterating the major themes on every occasion. The pursuit of collusion between Rich and Claridge, however, is unproductive in the sense that it would obscure rather than illuminate the complex processes that occurred. Equally, there is simply no need, or justification, for seeing the construction of the narrative as a conscious and deliberate application of sophisticated techniques; the coincidence of the imperatives of story telling, opposition politics and modern mass media production provide a richer source of understanding.

In the context of historical narrativity, Hayden White, summarising Gerard Genette, contrasts discursive subjectivity, deriving from the palpable presence of a sustaining ego, with narrative objectivity 'defined by the absence of all reference to the narrator'. ${ }^{50}$ This is the sense in which Claridge, despite her by-line, was narrator. White identifies the essence of narrativisation as the need to impose order on the disorder of events as they really occur, ${ }^{51}$ and discusses the necessity of reference to authority, consequent moralising and, above all, the delivery of the conclusion that the moralising permits 
and requires to the formation of narrative. ${ }^{52}$ It was the over-riding need for closure that united Rich and Claridge.

The ultimate parliamentary successes for an opposition politician, short of election victory, are, in order of rank, forcing the resignation of a minister, closure of a government agency and reversal of a major government policy. The possibility of a blow to the Community Employment Group had already been signalled in the August 2003 suspension of the SEF, and the possible role of the Tamati grant in furthering its closure is inherent in the unique formulation of the original parliamentary written question. ${ }^{53}$ While the taxpayer provided authority and travelling and chilling out the moralising, it was the inherent possibility of a closure, in both the political and narrative senses, that connected Rich and Claridge and informed the central definition of the issues.

In the Tamati inventory, as defined by Cohen, the taxpayer not only encapsulates the norm to which the Tamatis are other. It also, and particularly in the immediate aftermath of the coverage of Don Brash's Orewa speech condemning positive discrimination, discussed below, ${ }^{54}$ codes negative associations with the Samoanness of the Tamatis. Significantly, in light of the Brash speech, one journalist ascribed Māori identity to the Tamatis. ${ }^{55}$ The code was occasionally rendered explicit in, for instance, an editorial in the Press discussing the combustibility of the combination of job creation, 'minority races' and the poor, and excoriating the CEG for a tendency to 'kowtow to ethnic special pleading and political correctness' ${ }^{56}$ The taxpayer also placed the Tamatis in a negative relationship to the continuing political and media campaign for tax cuts. Travelling and chilling out invoked welfare abuse and idleness, the Paris stopover summoned up stereotypically wicked and erotic indulgence, while the Hawai'i and Fiji associations with chilling out called on centuries-old (mis)representations of the availability of exotic and erotic pleasure in the Pacific Islands.

If the taxpayer evoked resentment and travelling and chilling out envy, the role of hip hop was even more complex and, finally, powerful. I have already observed that the term 'hip hop' was omnipresent in the coverage of the grant, but that discussion of it was totally absent. At the same time, it is clear that it was the discourse about hip hop that played a major role in the CEG closure.

In Policing the Crisis, Hall and others refer to the importance of labels in not only placing and identifying events, but also in establishing and mobilising their entire referential context. ${ }^{57}$ They describe the introduction of the label 'mugging' in the 1970s:

"Mugging" comes to Britain first as an American phenomenon, but fully thematised and contextualised. It is embedded in a number of linked frames: the race conflict; the urban crisis; rising crime; the breakdown 
of "law and order"; the liberal conspiracy; the white backlash . . . The term is indexical ... The "mugging" label thus has a career. ${ }^{58}$

Noting that the label arrived sensational and sensationalised, they continue:

Thus, via the American transplant, Britain adopted, not only "mugging", but the fear and panic about "mugging" and the backlash reaction into which those fears and anxieties issued. If "mugging", by mid-1972, in Britain meant slums and cities and innocent folk and daylight robbery, it also meant liberal politicians versus decent white folks. ${ }^{59}$

This last point received some support from the Dominion Post editorialist who characterised the social entrepreneur grants as 'an example of the worst excesses of a liberal government' ${ }^{60}$ This description calls to mind both Edelman's observation of resentment of the use of taxes for welfare by the near-poor lower middle class and classical and neoclassic economists' distrust of market-distorting government intervention on behalf of the disadvantaged..$^{61}$

It is the discussion of mugging, however, that offers a solution to the mystery of the absence of hip hop from the coverage. While it would be easy and convincing to change 'mugging', Britain and the dates to describe more recent reactions to hip hop in some sections of New Zealand society, the Tamati inventory, to use Cohen's term, went further than that in its exclusion of any representation of the form to which constant but empty reference was made. A number of commentators have discussed negative reactions to hip hop and earlier popular music forms as they have appeared in Aotearoa New Zealand, ${ }^{62}$ but none of the commentary measures up to the scale of the associations with 'mugging' or with 'authentic' American hip hop. Any discussion of what it was about hip hop that transformed the Tamati grant into a scandal would have necessitated representation of hip hop's manifestations in Aotearoa New Zealand which would, in turn, have diminished the potential for the creation of fear carried by the pre-existing career of American hip hop, ${ }^{6.3}$ particularly when mainstream journals were celebrating the successes of the Aotearoa New Zealand form. ${ }^{64}$ Furthermore, those successes, and the personalities involved, would have diluted the 'stereotypical portrayal as atypical actors' of hip hop practitioners. ${ }^{65}$ As Edelman notes, "[t]he enemy themes that most surely and consistently evoke mass arousal and anxiety are those that make it hardest to take the enemy as a significant other'.66

This accounts for the erasure of Saralia Tamati, in her hip hop persona Spexone, and, for that matter, the nature and extent of Fuarosa's and other Tamatis' artistic and community experience. Any complete realisation of the two Tamatis in the press coverage would have provided an avenue to 
the artistic and commercial success that was being celebrated in popular journals and found expression in a long-standing and well-respected Christchurch Pacific Island performing tradition. The Pacific Underground milieu, fundamental to the context of the grant, and its production of such figures as Spexone, Phemone (Bonni Tamati), Ladi6 (Karoline Tamati) and Scribe (Malo Luafutu), not to mention popular TV and stage performers such as Oscar Kightley, was suppressed: ${ }^{67}$ Fuarosa Tamati was 'not a hiphop expert', ${ }^{68}$ and received only one, isolated, early mention in the New Zealand Herald as 'an aunt of artist Scribe',69 Pacific Underground's ten-year success was reduced to Vic Tamati's ' $\$ 80,000$ ' tattoo, tattoo itself being an age-old marker of deviance and transgression; ${ }^{70}$ Ladi6, as Karoline, made a brief appearance as the recipient of another dubious grant; ${ }^{71}$ and Spexone disappeared altogether.

The disembodied articulation of hip hop, the taxpayer, travelling, and chilling out, then, articulated in turn resentment, envy and fear, creating a potent moral panic, but one appearing in a form peculiar to the era of neoliberal economic fundamentalism: while the violence, crime and urban decay associated with American hip hop provided the element of fear, taxation, with its potential for the evocation of resentment, provided immediacy. All this did not, however, occur in a vacuum, and the question remains: what work did this narrative do in the world?

I have previously identified Katherine Rich as the progenitor of, and continuing resource for, this particular narrative. In quite a real sense it was Katherine Rich, not the Tamatis, that the story was 'about'. On one level, this is confirmed by the constant and major presence of Rich in Claridge's coverage and the interplay, at whatever distance, between them. On another level, Rich's direct statements as a commentator illuminate the authority and morality inherent in the narrative. A continuing but ambivalent resource, she is on record as supporting the principle of community development funding, but opposing both the kind and manner of the recent CEG grants. ${ }^{72}$ She is also on record as saying 'she had nothing against hip-hop' ${ }^{73}$ She has summarised her core position as follows in a report by Claridge:

I believe in the principles behind community development. But issues have been raised over the ones that $I$ would consider dodgy or of questionable benefit. What we need to do is eliminate those ones so that they don't cast a shadow over an entire programme which could be quite successful. ${ }^{74}$

Rich has not indicated the nature of community development that she does support, limiting herself to contrasting the 'dodgy' grants with needs such as education and healthcare for Pacific Island children, 6000 children waiting to see a social worker and the inevitable hip operations. ${ }^{75}$ She has, 
however, characterised the SEF as 'a slushy, politically correct outlet for the Government to please community groups'; it is 'one of the largest government slush funds in history' and the purpose of the grants is 'funding pet projects for the Government, not community development' ${ }^{6}$

In particular, in response to a Claridge revelation that 50 percent of CEG funding went to Māori, and 20 percent to Pacific Islanders, Rich accused the CEG of operating 'blatant race-based policies', and was indirectly reported as claiming that 'the Government has been caught red-handed giving preferential treatment to Maori and Pacific Islanders'. She continued:

The Community Employment Group invests in the community, therefore their investment should reflect their communities and Maori and Pacific Islanders do not make up $70 \%$ of the community. This is particularly so in the South Island . . .77

Rich had earlier been reported as saying that opposition to the Tamati grant 'was about the waste of taxpayers [sicl money, not racism'?

Her comments on the closure of the CEG and the SEF also reflect other ambiguities. On the one hand she was reported as saying that she had 'never called for the group to go', and had only wanted the tightening of monitoring and accountability; ${ }^{79}$ on the other, she claimed that:

[t] he writing has been on the wall for the Social Entrepreneur scheme from the very beginning. It could not continue wasting money on things like hip-hop tours, which involved chill-out sessions in Hawaii and Paris. ${ }^{80}$

She described the closure of the CEG as 'a blatantly transparent attempt to shut down ... political fall-out', ${ }^{\prime 1}$ and, on the establishment of the replacement Community Initiatives Fund, described it as the 'hip-hop fund in drag'. 'Few changes had been made to the criteria, aside from a couple of minor ones to prevent grants such as the hip-hop one being awarded'. ${ }^{.2}$

Another key event in the period over which Rich's story was narrated, chiefly by Claridge, provides a further suggestion as to what it was that was being played out. January 2004 was the moment of the major speech by the National party opposition leader, Don Brash, attacking recent examples of positive discrimination towards Māori, Treaty of Waitangi implementation and 'race-based' policies, and calling for 'one standard of citizenship for all. ${ }^{83}$ The speech was something of an innovation in this country as a major initiative in wedge politics, that is, 'targeting unpopular or stigmatised social issues or groups as a way of defining "mainstream politics" and linking political opponents to their support of these issues or groups" ${ }^{84}$ It received intensive coverage before and during the period of the Rich narrative and was, for a time, responsible for an unprecedented leap in the National party's poll ratings. In essence, the key to the selectivities and emphases of the Rich 
narrative, and one supported by the trajectory of its own career, is that it too was a manifestation of wedge politics, if one with particular nuances of its own. The Rich story was a micronarrative running subsidiary to the Brash macronarrative, a coupling facilitated in part by the ambiguity of the family name Tamati, one, with a different stress, more commonly associated with Māori. That a connection existed between the two narratives, as well as the longevity of the scandal, is borne out by the 2005 National party election billboard linking 'hip-hop tours' with 'welfare bribes, prisoner compo, twilight golf, sing-along courses, taniwha, more bureaucrats, NCEA inquiries, Treaty lawyers . . .

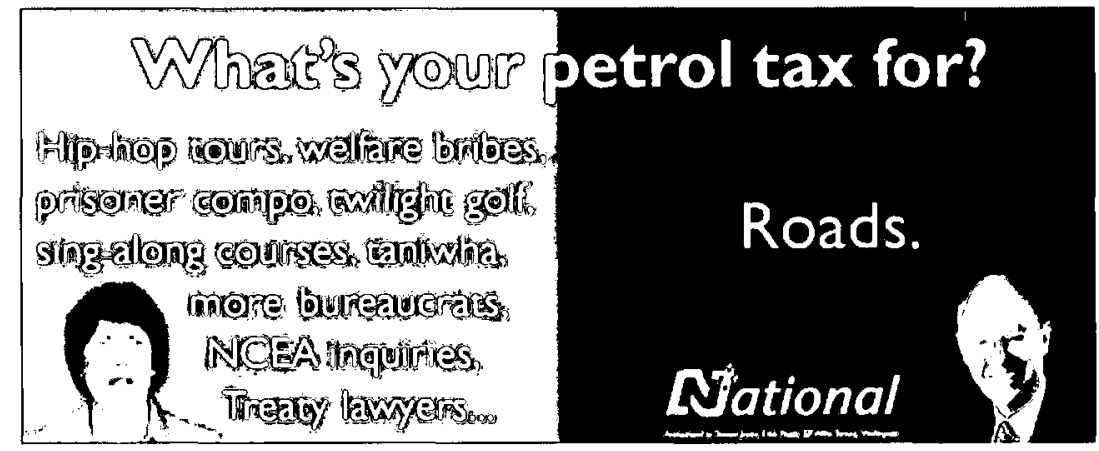

Like the Brash example, Rich's narrative was not, eventually, entirely successful at the level of national parliamentary politics. The Labour government, already learning from the early checks of the Brash episode, virtually closed down bureaucratic comment from the end of March, and thereafter confined political comment to the Prime Minister, who had described unspecified grants as 'loopy' and 'silliness'. ${ }^{85}$ The earlier freezing of the SEF and the 1 July closure of the CEG, along with diminishing returns from the Brash initiative, diverted most journalistic attention away from the Tamati grant, hence Rich's expression of frustration at the government's 'blatantly transparent attempt to shut down the political fall-out' ${ }^{86}$ In fact, I would suggest that the source of at least some of her ambivalence lay in the tension between the rival attractions of closure of the agency and continuation of the wedge strategy.

Rich's mixed response to the new Community Initiatives Fund has already been noted: on the one hand it was the CEG 'in drag'; on the other, it would prevent the awarding of grants such as the 'hip-hop' one. In light of the strategy employed in the construction of the narrative, and the force of the evidence that it was not hip hop itself that was at issue, there remain only the other components of Fuarosa and Saralia Tamati's project to turn to for 
an explanation of what it was that invited closure, and why. The absence from the political debate and press coverage of those elements of the project, and their juxtaposition of Pacific youth, autonomous creative expression and an empowering model of community development, may provide the most telling evidence of the true nature of the great hip hop grant scandal.

\section{Conclusion}

By dint of selection of only a fraction of the information publicly available about the project and grant, the print coverage was able to evoke three dominant discourses in the public narrative of the late twentieth and early twenty-first centuries in Aotearoa New Zealand: that of the long-suffering, hard-working taxpayer; that of the marginal figures who live on an unfair share of the earnings of those taxpayers without contributing to society; and that of the danger and otherness of hip hop.

In making her selection, Claridge, the invisible narrator, called on a small cast of characters: Rich, both objective commentator and spokesperson for the taxpayer; Fuarosa Tamati, brown, beneficiary and associated with hip hop; and the Labour government, panderer to the Tamatis and PC scourge of the hard-working taxpayer. The taxpayer's resentment and envy, articulated by Rich, provided the source of authority to which the narrative made appeal; Fuarosa Tamati became the target of moralising on behalf of the taxpayer; and the Labour government constituted the obstacle to closure, the necessary outcome permitted and demanded by the moralising.

Narrative as well as literal closure, if a somewhat ambivalent one with the establishment of the Community Initiatives Fund, was achieved by the freezing of the Social Entrepreneur Fund and the 1 July closing down of the Community Employment Group. It was as a result of that closure that the audit report, and its exoneration of Fuarosa and Saralia Tamati, served only as an anticlimax that could be virtually passed over. In the end, the report was dismissed by Claridge with the words, 'the Christchurch mother and daughter escaped criticism'. ${ }^{87}$

1 Russell Third, Shane Nicholas, and Wendy Wong. Audit Report on Community Employment Group Grant, Wellington: Department of Labour/Te Tari Mahi, 2004, pp.10, 13-14.

2 Fuarosa Tamati and Saralia Tamati, [Final Report to the Community Employment Groupl, 18 September 2003; Katherine Rich, to the Minister for Social Development and Employment, 'Questions for Written Answer', March 2004, http://publications.clerk .parliament.govt.nz.clients.intergen.net.nz/QuestionsForWrittenAnswerSearch.aspx?Mem berName=Rich\%20Katherine\&MinisterName $=$ Maharey $\% 20$ Hon\%20Steve\&Portfolio $=\&$ MonthLodged $=3 \&$ YearLodged $=2004 \&$ QuestionNumber $=\&$ Keyword $=$ community $\% 20 \mathrm{e}$ mployment \%20group\&SearchReply=1\&RefineSearchKeyword=\&SearchButton=Search, accessed 10 January 2005. 
3 The sample upon which the survey is based was derived by searching The Knowledge Basket's Newztext Plus database on hip hop and grant for print media from I January to 12 December 2004. The search elicited items from the Dominion Post, Independent, National Business Review, Nelson Mail, New Zealand Herald, The Press, Southland Times, Sunday Star Times, Timaru Herald, Truth, and Waikato Times. The Daily News, Evening Standard, and Sunday Times are also covered by the database, but no material emerged. One other item was added from hard copy (Bell 26 October 2004). In total there were 106 items, including editorials, comment pieces and letters to the editor, as well as news stories. All of the citations include page numbers except for items from the New Zealand Herald; for an unexplained reason, the database records them at the time of filing on the Herald website, though the items are from the print edition.

4 Hayden White, The Content of the Form: Narrative Discourse and Historical Representation, Baltimore, 1987, pp.19-25,

5 David L. Altheide, Creating Fear: News and the Construction of Crisis, New York, 2002, pp.31-38.

6 Murray Edelman, The Politics of Misinformation, Cambridge, 2001, p.61.

7 Stuart Hall, Chas Critcher, Tony Jefferson, John Clarke and Brian Roberts, Policing the Crisis: Mugging, the State, and Law and Order, London, 1978, pp.57-58.

8 Stanley Cohen, Folk Devils and Moral Panics, 3rd ed., London, 2002, pp.7, 31.

9 Edelman, Politics of Misinformation, pp.55-60.

10 Cohen, pp.31-32.

1 Hall et al., p.54.

12 Cohen, p.162.

13 Ibid., p.1.

14 Ibid., p.167.

15 Department of Labour (DoL), Report of the Department of Labour/Te Tari Mahi for the Year Ended 30 June 2003, Wellington, 2003, p.57.

16 DoL. Report of the Department of Labour/Te Tari Mahi for the Year Ended 30 June 2004, Wellington, 2004, p.186.

17 DoL, 2004, pp.148-9.

18 Third, p.10.

19 lbid., p.11.

20 DoL, 2003, p.57.

21 DoL, 2004, p.148.

22 Third, pp.20, 24.

23 lbid., pp.13-14, 26-27.

24 lbid., pp.26-32.

25 Ibid., p.28.

26 Ibid., p.27.

27 Ibid., p.27.

28 lbid., pp.14, 32

29 Press (P), 'Govt tightens hold on grants', 30 March 2004.

30 Rich Katherine, to the Minister for Social Development and Employment, 'Questions for Written Answer', February 2004, http:/publications.clerk.parliament.govt.nz.clients .intergen.net.nz/QuestionsForWrittenAnswerSearch.aspx?MemberName=Rich\%20Kather ine\&MinisterNane=Maharey\%20Hon\%20Steve\&Portfolio=\&MonthLodged=2\&YearLod ged $=2004 \&$ QuestionNumber $=\&$ Keyword=community\%20employment $\% 20$ group $\&$ Search Reply=1\&RefineSearchKeyword $=\&$ SearchButton=Search, accessed 10 January 2005.

31 Ibid.

32 Rich, March 2004.

33 Ibid.: P, '\$80.000 for tattoo show', 25 March 2004. 


\section{The Great Hip Hop Grant Scandal}

34 Rich, March 2004.

35 Ibid.

36 Ibid.

37 P, 'Sour note for taxpayers over pair's hip-hop tour', 17 March 2004

38 P, 'Trip hop for hip-hop defended', 18 March 2004.

39 Katherine Rich, "Maharey must explain hip-hoppers "chill out", National party press release, 18 March 2004.

40 P, 'Hip-hopper family link', 20 March 2004.

41 P, 'Blunders highlighted in hip-hop grant report', 3 September 2004; Sunday Star-Times (SS-T), "Social entrepreneurs" 70-day world tour gets nod', 29 August 2005; Dominion Post (DP), 'What the taxpayer got for \$26,000', 3 September 2004.

42 P. 'Hip-hopper family link', 20 March 2004; P. 'Hip-hop trip "justified”', 23 March 2004; $P$, ' $\$ 10,000$ forked out for strippers', 3 April 2004.

$43 \mathrm{NZ}$ Herald (NZH), 'Best result from studies of hip hop', editorial, 22 September 2004.

$44 \mathrm{NZH}$, 'Comedian says social entrepreneur grant well spent', 26 March 2004.

45 DP, 'Outdoor lifestyle ventures', 30 March 2004.

46 DP, 'Publisher thrives on hip hop', 26 October 2004.

47 SS-T, “'Social entrepreneurs" 70-day trip gets nod', 29 August 2004.

48 P, 'Hip-hop funding', letter to the editor, I April 2004; P, 'Accountability lacking', editorial, 4 September 2004.

$49 \mathrm{NZH}$, 'Best result from studies of hip hop', editorial, 22 September 2004.

50 White, 1987, p.3.

51 Ibid., p.4.

52 lbid., pp.19-25.

53 Rich, February 2004.

$54 \mathrm{NZH}$, 'Brash plotting to extend magic run', 17 April 2004.

$55 \mathrm{P}$, 'Keeping an eye on the gap', 12 July 2004.

56 P, 'More scrutiny needed', editorial, 22 September 2004.

57 Hall, p.19.

58 Jbid., p.27.

59 Ibid., p.28.

60 DP. 'Poor custodians of our money', editorial, 7 July 2004.

6] Edelman, Politics of Misinformation, pp.62-64.

62 Tania Kopytko, 'Breakdance as an Identity Marker in New Zealand', Yearbook for Traditional Music, XVIII, 1986, pp.21-27; Tony Mitchell, 'Aotearoa Hip Hop in the 21 st Century', unpublished conference paper, Music and Locality: Towards a Local Discourse in Music, Victoria University of Wellington, 2003; Tony Mitchell and Roy Shuker, 'Moral Panics, National Pride and Split Images: Music and the Press in Aotearoa/ New Zealand', Perfect Beat, 10, 2, January 1998, pp 51-67; Mark Scott, Street Action Aotearoa, Auckland, 1985; Roy Shuker and Roger Openshaw with Janet Soler, Youth, Media and Moral Panic in New Zealand (From Hooligans to Video Nasties), Delta Research Monograph 11, Palmerston North, 1990; Kirsten Zemke-White, 'Rap Music in Aotearoa: A Sociological and Musicological Analysis', unpublished PhD thesis, University of Auckland.

63 Murray Forman, The 'Hood Comes First: Race, Space, and Place in Rap and HipHop, Middletown Connecticut, 2002; Tricia Rose, 'Rap Music and the Demonization of Young Black Males', USA Today Magazine, 122, 2588, May 1994, pp.35-6; Tricia Rose, Black Noise: Rap Music and Black Culture in Contemporary America, New Hampshire, 1994. 


\section{Journal of New Zealand Studies}

64 Stephen Jewell, 'Rapture (Mareko and Scribe)', Pavement, August/September 2003, pp.104-7; Veronica Schmidt, 'Not Many, If Any', NZ Listener, 191, 320, 27 December-2 January 2003-04, cover, pp.14-17.

65 Cohen, p.45.

66 Edelman, Politics as Symbolic Action, p.115.

67 Janet McAllister, 'Homegirls', Canvas, Weekend Herald, 15 January 2005, pp.10-13; Felolini Maria Ifopo, 'Famously Fresh', Spasifik, 6, January-February 2005, pp.54-56.

68 P, 'Trip hop for hip-hop defended', 18 March 2004.

$69 \mathrm{NZH}$, 'Agency tells how cash for hip-hop trip doled out', 20 March 2004.

70 P, ' $\$ 80,000$ for tattoo show', 25 March 2004.

71 P, 'Hip-hop trip "justified", 23 March 2004.

72 P, 'Hip-hop timeline', 27 March 2004.

73 Independent, 'Report blasts \$22m “closing the gaps" spend-up'. 21 July 2004.

74 P, 'Monitoring of organisations awarded grants', 27 March 2004.

75 P. 'Trip hop for hip-hop defended', 18 March 2004.

$76 \mathrm{P}$, 'Monitoring of organisations awarded grants', 27 March 2004; 'Blunders highlighted in hip-hop trip report', 3 September 2004.

77 P, 'Maori get half of CEG cash', 3 June 2004.

78 NZH, 'Turia backs hip-hop grant', 3 April 2004.

$79 \mathrm{NZH}$, 'Grant cash in doubt after agency axed', 21 September 2004.

80 P, 'Govt axes hip-hop travel fund', 2 July 2004, emphasis added.

81 P, 'Questions about CEG move', 21 September 2004, emphasis added.

$82 \mathrm{NZH}$, "New scheme is hip-hop fund in drag', 3 November 2004.

83 Don Brash, 'Nationhood, An Address by Don Brash, Leader of the National Party, to the Orewa Rotary Club on 27 January 2004', http://www.national.org.nz/Article. aspx?articleId $=1614$, accessed 30 January 2005.

84 Shaun Wilson and Nick Turnbull, 'Wedge Politics and Welfare Reform in Australia', Australian Journal of Politics and History, 47, 3, 2001, p.385.

$85 \mathrm{NZH}$, 'Comedian says social entrepreneur grant well spent', 26 March 2004; DP, 'PM stops hip-hop "silliness", 30 March 2004.

86 P, 'Questions about CEG move', 21 September 2004.

87 P, 'Blunders highlighted in hip-hop grant report', 3 September 2004 